\title{
What are the Critical Success Factors for Microbusiness Survival?
}

By

Debra Frank, University of South Florida

$\mathrm{W}$ hen COVID-19's shutdown rolled out, many owner-manager entrepreneurs were forced to close their microbusinesses since their businesses were not considered essential services and activities. These microbusinesses had to scramble to find new ways to conduct business and retain customers to survive. This research question review summarizes key critical success factors that would help prevent microbusinesses from permanent closure. The seven success factors identified in this paper are: Management Skills, Learning Agility, Survival Tactics, Technology, Community, Business Alliances, and Marketing. These identified success factors could lead future research to develop suggestive models for microbusinesses to follow for closure preventions.

Keywords: microbusinesses, critical success factors, closure prevention, management skills

Copyright $\odot 2021$ Debra Frank. This article is published under a Creative Commons BY-NC license. Permission is granted to copy and distribute this article for non-commercial purposes, in both printed and electronic formats 
The motivation for this research question arises from observing several microbusiness operations during the COVID-19 pandemic and their maneuvers to survive. Closures during 2020 were elevated at least among small firms and particularly in industries most sensitive to social distancing (Crane et al., 2020). The context of this Research Question Review is to discover what critical success factors (CSFs) are required for preventing permanent microbusiness closures.

Extensive research has been done on small business, but little research has been done on microbusinesses specifically. Although not one definite definition for microbusinesses exists, resources cite that they are businesses with nine or fewer full-time employees (Headd, 2017). Microbusiness uniqueness should

\section{Protocol}

The general databases searched included Google Scholar via Harzing's Publish or Perish software and $\mathrm{ABI} /$ Global Database via the Library Services link on MyUSF portal. The keywords used in these databases were: microbusiness crisis, microbusiness resilience, and microbusiness success factors. Most matches were from developing countries and had little application to the U.S. However, there were a few from the U.S. and several from European countries with similar economies. Ultimately, only 14 articles matched the criteria for keywords in similar economies. These articles were downloaded to EndNote for citation. An additional 12 articles were cited from those 14 articles' references. Two additional references were also used from the U.S. Small Business Administration (SBA) and the Federal Reserve's Finance and Economics Discussion series (FEDS). As a result, a total of 28 references were cited. not be overlooked as microbusiness employers comprise 74.8 percent of all private-sector employers in the United States in 2016, and they provide 10.3 percent of private sector jobs (Headd, 2017).

Not much existing research is found on microbusinesses, specifically located within the United States; most microbusiness research is within developing countries. As a result, a clear gap exists in scholarship on microbusinesses, though they play a major role in the U.S. economy. This paper plans to extend the knowledge obtained for microbusinesses' use by identifying key CSFs used for resilience. Reviewing what CSFs should be in place could offer insight to microbusinesses for survival and closure prevention.

This paper begins with summarizing the protocol used to identify the articles covered in the review. Then, key findings from the articles are presented in a series of two tables that include definitions for the base constructs and key themes discovered. The tables lead into a discussion section where the findings are summarized into a diagram that captures the key themes identified in the study. Finally, the paper concludes by returning to our original research question and summarizing what was learned in the process.

\section{Literature Summary}

The following tables identify definitions for base constructs and common critical success factors found for a successful microbusiness. Table $1 \mathrm{de}-$ fines the base constructs for microbusinesses and resilience. Then, Table 2 summarizes main themes that are internally within the microbusiness. Table 3 summarizes external critical success factors.

Table 1 defines the base constructs of a microbusiness and the term resilience in the context of this research question review. Brian Headd (2017), Research Economist for the U.S. Small Business Administration (SBA), states in the SBA infographic for

Table 1: Defining the Base Constructs

\begin{tabular}{|l|l|}
\hline \multicolumn{1}{|c|}{ Finding } & \multicolumn{1}{c|}{ Sources } \\
\hline $\begin{array}{l}\text { A microbusiness (MB) is a business with 9 or less full-time } \\
\text { employees. }\end{array}$ & $\begin{array}{l}\text { (Headd, 2017); (Rupasingha, 2017); } \\
\text { (Gherhes et al., 2016); (Drnevich } \\
\text { \& West, 2021); (Van Hoang et al., } \\
\text { 2018); (Branicki et al., 2018); (Bou- } \\
\text { ette \& Magee, 2015); (Barnes et al., } \\
\text { 2012); (Perren, 2000a); (Baines \& } \\
\text { Wheelock, 1998) }\end{array}$ \\
\hline $\begin{array}{l}\text { A microbusiness distinguishes themselves from larger SMEs by } \\
\text { being owner-manager entrepreneur (OME) centric. }\end{array}$ & $\begin{array}{l}\text { (Gherhes et al., 2016); (Hayes et al., } \\
\text { 2015); (Perren, 2000a) }\end{array}$ \\
\hline $\begin{array}{l}\text { Organizational resilience is defined as the ability to adapt to } \\
\text { change in the context of extreme events (e.g., natural disasters, } \\
\text { pandemic disease, and terrorism). }\end{array}$ & $\begin{array}{l}\text { (Branicki et al., 2018); (Yang \& } \\
\text { Danes, 2015) }\end{array}$ \\
\hline
\end{tabular}


Table 2: Internal Critical Success Factors (CSFs) for Closure Prevention of Microbusiness

\begin{tabular}{|c|c|c|}
\hline Construct & Findings & Sources \\
\hline $\begin{array}{l}\text { Management's } \\
\text { Skills: }\end{array}$ & $\begin{array}{l}\text { Successful entrepreneurs possess well-es- } \\
\text { tablished survival instincts, as they have a } \\
\text { positive attitude toward risk, remain posi- } \\
\text { tive in the face of setbacks, and sometimes } \\
\text { view failure as an opportunity to renew or } \\
\text { re-start. } \\
\text { The critical role those individual entrepre- } \\
\text { neurs play in promoting these alternative } \\
\text { sources of resilience through their atti- } \\
\text { tudes and behaviors. } \\
\text { The most important skills for a successful } \\
\text { practice were artistic, problem solving, } \\
\text { communication, marketing, adaptability, } \\
\text { technology, and new media. } \\
\text { The importance of acting like strategic } \\
\text { entrepreneurs, rather than enthusiastic } \\
\text { opportunity seekers. } \\
\text { Resilience within the entrepreneurship lit- } \\
\text { erature has been primarily conceptualized } \\
\text { as either a trait or a state of entrepreneurs. } \\
\text { Accessing and using internal resources to } \\
\text { operate as protective mechanisms against } \\
\text { the demands of stressor events. } \\
\text { Business confidence is built on both mas- } \\
\text { tery and positive self-evaluation, both of } \\
\text { which are valuable qualities for entrepre- } \\
\text { neurs. } \\
\text { The founder's experience and skills and } \\
\text { abilities were identified as CSFs. } \\
\text { Entrepreneurs are generally associat- } \\
\text { ed with independence and innovation, } \\
\text { breaking existing modes of organizing and } \\
\text { producing goods and services. } \\
\text { It is the owner-manager, his traits and } \\
\text { background, which are among the most } \\
\text { important factors. } \\
\text { The owner-manager being willing to } \\
\text { accept the risk of challenging orders or } \\
\text { opportunities can be a positive influence } \\
\text { (active risk taker). } \\
\text { Active risk taker, owner's motivation, } \\
\text { innovator skills }\end{array}$ & $\begin{array}{l}\text { (Hayes et al., 2015) } \\
\text { (Nieminen \& Lemmetyinen, 2015) } \\
\text { (Lean, 1998) } \\
\text { (Perren, 2000a) } \\
\text { (Perren, 2000b) }\end{array}$ \\
\hline
\end{tabular}




\begin{tabular}{|c|c|c|}
\hline Learning Agility: & $\begin{array}{l}\text { It is essential for OMEs to develop the abil- } \\
\text { ity to learn from experience, "one of the } \\
\text { key abilities in entrepreneurship." } \\
\text { To sustain their work and manage their } \\
\text { careers across multiple economic sectors, } \\
\text { creative workers create their own learning } \\
\text { experiences, build a broad base of skills } \\
\text { and networks, and remain informed of } \\
\text { industry trends. } \\
\text { Research set specifically in the micro busi- } \\
\text { ness context reflects this ongoing, busi- } \\
\text { ness-based nature of learning. } \\
\text { Learning is the by-product of a business } \\
\text { process }\end{array}$ & $\begin{array}{l}\text { (Hennekam \& Bennett, 2017) } \\
\text { (Devins et al., 2005) }\end{array}$ \\
\hline Survival Tactics: & $\begin{array}{l}\text { Using these survival techniques, many } \\
\text { MEs [Micro-enterprises] traversed this dif- } \\
\text { ficult economic period without too much } \\
\text { harm, preserving their core competence } \\
\text { and market positioning. } \\
\text { Creating a team and employing staff } \\
\text { Repeated positive interactions create } \\
\text { positive expectations; these positive expe- } \\
\text { riences enhance the likelihood of future } \\
\text { interactions. } \\
\text { Ability to communicate with customer }\end{array}$ & $\begin{array}{l}\text { (Van Hoang et al., 2018) } \\
\text { (Bouette \& Magee, 2015) } \\
\text { (Kelliher et al., 2018) } \\
\text { (Lean, 1998) }\end{array}$ \\
\hline Technology: & $\begin{array}{l}\text { New website and new email application for } \\
\text { effective marketing of products } \\
\text { Use of Information and Communication } \\
\text { Technology (ICT) technologies and bene- } \\
\text { fited with new customers and new business } \\
\text { model. } \\
\text { Strong Information Technology skills and } \\
\text { operations. } \\
\text { ICT benefits identified in categories as } \\
\text { internal operational efficiency, enhanced } \\
\text { capability, external communications, } \\
\text { enhanced service offerings and lifestyle } \\
\text { benefits }\end{array}$ & $\begin{array}{l}\text { (Jones et al., 2014) } \\
\text { (Fielden et al., 2000) } \\
\text { (Barnes et al., 2012) }\end{array}$ \\
\hline Marketing: & $\begin{array}{l}\text { They competed mainly by developing the } \\
\text { intangible assets of the firm, in terms of } \\
\text { human skills, advertising, networking, } \\
\text { brand name, and customer awareness. } \\
\text { Brand awareness, availability, and visibili- } \\
\text { ty build revenues and new business oppor- } \\
\text { tunities for the small business organiza- } \\
\text { tion. } \\
\text { Building brand-identity } \\
\text { Marketing issues was found to be a major } \\
\text { factor for microbusiness problems }\end{array}$ & $\begin{array}{l}\text { (Van Hoang et al., 2018) } \\
\text { (Yang, 2016) } \\
\text { (Nieminen \& Lemmetyinen, 2015) } \\
\text { (Hayes et al., 2015) }\end{array}$ \\
\hline
\end{tabular}


microbusinesses that "While no definitive definition exists, microbusinesses are defined here as employers with fewer than 10 employees" (Headd, 2017, p. 1). Additional resources cited are from the United States and European countries with similar economic environments to the United States. For the purposes of this literature review, microbusinesses are owner-manager entrepreneurs (OMEs) as well (Gherhes et al., 2016). Also, the term resilience, in the context of microbusinesses, is the ability to adapt to change (Branicki et al., 2018).

Table 2 summarizes four main themes for internal CSFs required by microbusinesses for closure prevention. These themes are management skills, learning agility, survival tactics, technology, and marketing.

Table 3 summarizes three prominent themes of externally related CSFs for closure prevention. These themes are community and business alliances.

\section{Discussion}

Most research found on microbusinesses is from developing countries. Some literature was found from
European sources; since Europe and the U.S. both have similar economies, European research is used. Although the U.S. and European economies are similar, less research is done from within the United States. Three of every four businesses in the United States are microbusinesses (Brawley \& Pury, 2017). The research available on U.S. microbusinesses is not nearly as extensive as the European research found, though the microbusiness industry in the United States is considerable.

As illustrated in Tables 2 and 3, common CSFs are found for preventing microbusiness closure. The CSFs summarized within the tables identify seven success factors for microbusinesses: Management Skills, Learning Agility, Survival Tactics, Technology, Marketing, Community, and Business Alliances.

Management skills include the entrepreneur's attitude towards risk, commonly referred to as being an "active risk taker" (Perren, 2000b). The OME remains positive when he/she meets setbacks and demonstrates resilience with his/her experience and problem-solving skills. The microbusiness gains learning agility that helps prevent closures, whether

\begin{tabular}{|l|l|l|}
\hline Table 3: External Critical Success Factors (CSFs) for Closure Prevention of Microbusinesses \\
\hline Construct & \multicolumn{1}{|c|}{ Findings } & \multicolumn{1}{|c|}{ Sources } \\
\hline Community: & $\begin{array}{l}\text { "In small firms which are embedded } \\
\text { into their local community such as a } \\
\text { micro-brewery where all other stakehold- } \\
\text { ers are also drawn from that same local } \\
\text { community, 'the community' may be at } \\
\text { the center of the stakeholder map of which } \\
\text { the small firm is a satellite." }\end{array}$ & (Spence, 2016) \\
& $\begin{array}{l}\text { The business was supported by a hard-core } \\
\text { group of loyal customers from the local } \\
\text { community or by their family network. }\end{array}$ & (Van Hoang et al., 2018) \\
& $\begin{array}{l}\text { Rural micro firms are embedded in the } \\
\text { social context of the rural community } \\
\text { where repeated positive interactions lead } \\
\text { to a cyclical process of mutual learning, } \\
\text { exploration, testing and negotiation. } \\
\text { Effective business learning from getting } \\
\text { information and ideas through contacts. } \\
\text { Being fully immersed in the field both in a } \\
\text { professional and social capacity. } \\
\text { Involvement in local Chamber of Com- } \\
\text { merce. } \\
\text { Extensive or moderate participation net- } \\
\text { works which are either business related or } \\
\text { a combination of business and social. }\end{array}$ & (Kelliher et al., 2018) \\
\hline & (Baffo et al., 2000) \\
\hline
\end{tabular}




\begin{tabular}{|l|l|l|}
\hline $\begin{array}{l}\text { Business Allianc- } \\
\text { es: }\end{array}$ & $\begin{array}{l}\text { Networks which offer other opportunities } \\
\text { for shared services and business acumen } \\
\text { workshops. } \\
\text { An environment within which the MB } \\
\text { [Microbusiness] participants could take a } \\
\text { step back from running their businesses, } \\
\text { enabled them to engage with a process, } \\
\text { whereby they could assume a different } \\
\text { identity and feel part of a connected sup- } \\
\text { portive business community. } \\
\text { Programs that seek to encourage net- } \\
\text { working and knowledge sharing between } \\
\text { larger SMEs and micro-businesses are also } \\
\text { key to promoting growth through busi- } \\
\text { ness-to-business collaboration. } \\
\text { The most useful information is obtained } \\
\text { from someone known from experience to } \\
\text { be reliable. } \\
\text { Business networks and the support can } \\
\text { offer help in overcoming such barriers to } \\
\text { survival and progression. } \\
\text { However, many small businesses also } \\
\text { operate collaboratively, working close- } \\
\text { ly with other small businesses, seeking } \\
\text { complementary resources and expertise, } \\
\text { to overcome their individual paucities of } \\
\text { resources and expertise. }\end{array}$ & (Gherhes et al., 2016) \\
\hline
\end{tabular}

it be the businesses' operations or the OME's ability to learn (Gherhes et al., 2016). In addition, survival tactics prevent closures for the microbusiness that help keep its core business and market place (Van Hoang et al., 2018). The use of technology, such as information and communication technology (ICT), up to date websites, and email applications for effective marketing, helps to prevent closures (Jones et al., 2014). Lastly, developing a strong brand awareness with the community through marketing helps the microbusinesses survive.

Community is an external force that helps support microbusinesses. The businesses supported by a hard-core group of loyal customers from the local community or their family network can sustain difficult times (Van Hoang et al., 2018). Business alliances for microbusinesses provide a network of sharing of information and support with each other. They offer help in overcoming barriers to survival and progression (Fielden et al., 2000).

Figure 1 below summarizes the internal and external CSFs from the literature review process. While reviewing the management skills construct, it became clear that without these skills, many of the other constructs could not be successful. For example, unsuccessful survival tactics may be executed when there is not an OME who possessed strategic skills. These strategic skills could be categorized as the
OME's innovativeness, stress tolerance, and proactive personality (Branicki et al., 2018). Furthermore, the microbusinesses' learning agility could start with management's resilience and willingness to tackle problem solving. Micro-business managers deliberately experiment to acquire new knowledge (Devins et al., 2005). This requires active risk taker skills.

External CSFs are connected to each other as well. A microbusinesses' community would include business alliances. Business alliance is the idea of having shared identity, shared values, and shared goals in staying in business, which is achieved for the most part in the culture of a shared learning environment (Gray \& Jones, 2016). Within the microbusinesses' environment, their networks for collaboration are usually part of their learning community. Networks are used for the exchange of new knowledge and skills (Nieminen \& Lemmetyinen, 2015).

An overlap between the internal and external CSFs are noticeable too. These constructs include:

- Successful marketing in the internal aspect linked with the microbusiness having successful information and communication technology

- Survival tactics and learning agility for the OME obtained from the exchange of new knowledge and skills with the community and business alliances 


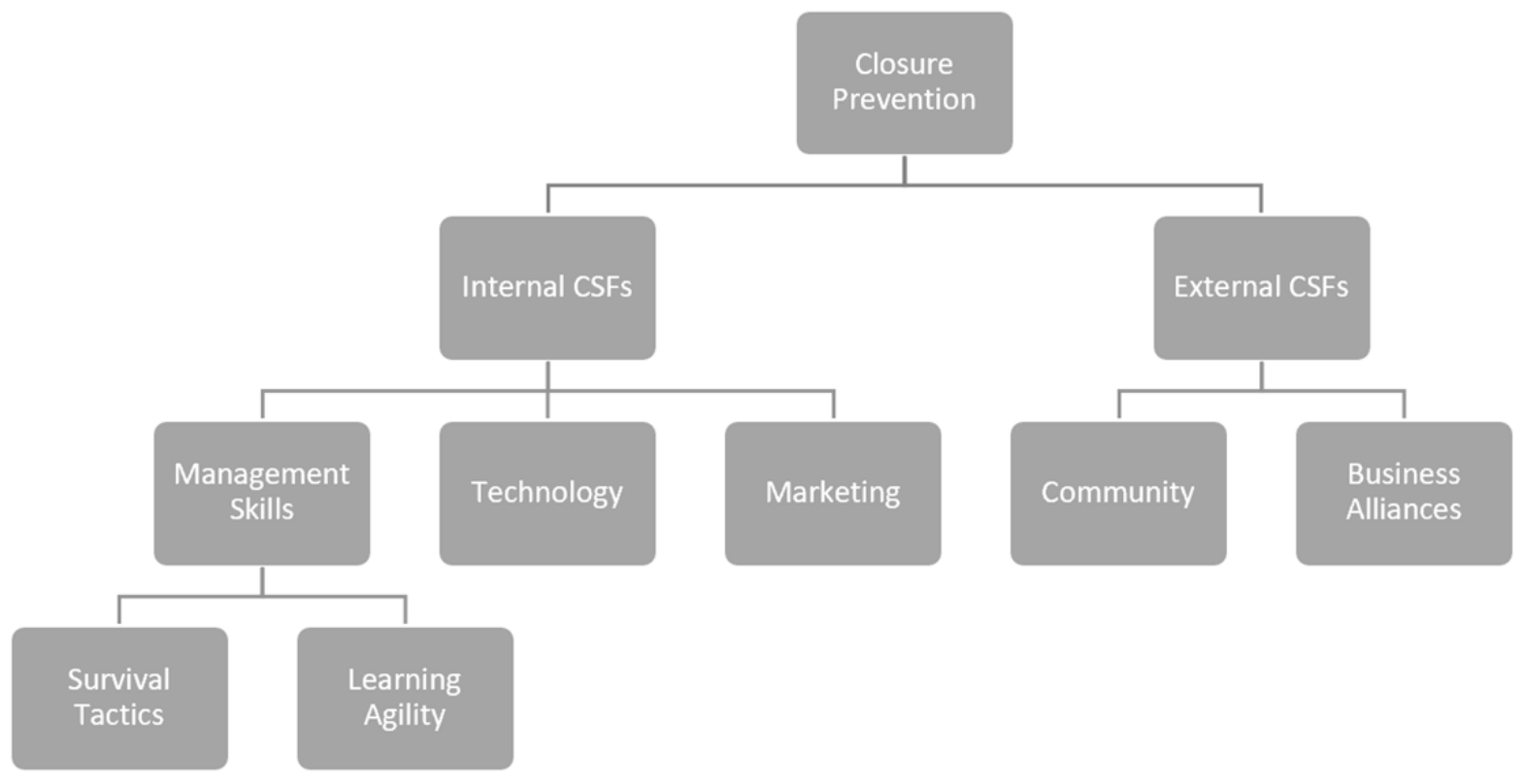

Figure 1: Internal and External CSFs

\section{Conclusions}

This Research Question Review sought to identify critical success factors (CSFs) necessary to prevent microbusiness closure. The literature has many CSFs identified for a successful microbusiness, but little is written on closure prevention specifically. In addition, there is a lack of research literature on U.S. microbusinesses, though microbusinesses have a significant impact within the United States. A gap exists in the literature on U.S. microbusinesses and key critical success factors for closure preventions.

Key Takeaways:

- There are seven commonly found CSFs that successful microbusinesses could have; these CSFs have overlapping qualities.

- Management skills play a lead role in prevention of microbusiness closure.

- There is a link between the internal and external critical success factors for closure prevention.

- A gap exists in U.S. microbusiness literature and closure preventions.

There are potential opportunities for future research on success factors for microbusiness closure preventions. Further research will help build models for U.S. microbusinesses to adopt for help with strengthening their businesses as well as the ultimate likelihood of surviving. In addition, possible exploration, and comparison of CSFs from non-microbusinesses could be done to discuss why they may or may not work for microbusinesses.

\section{References}

Baines, S., \& Wheelock, J. (1998). Working for Each Other: Gender, the Household and Micro-business Survival and Growth. (1), 16. https://doi. org/10.1177/0266242698171001

Barnes, D., Clear, F., Dyerson, R., Harindranath, G., Harris, L., \& Rae, A. (2012). Web 2.0 and micro-businesses: an exploratory investigation. (4), 687. https://doi.org/10.1108/14626001211277479

Bouette, M., \& Magee, F. (2015). Hobbyists, artisans and entrepreneurs. Journal of Small Business and Enterprise Development, 22(2), 337351. https://doi.org/http://dx.doi.org/10.1108/ SSBED-02-2013-0022

Branicki, L. J., Sullivan-Taylor, B., \& Livschitz, S. R. (2018). How entrepreneurial resilience generates resilient SMEs. International Journal of Entrepreneurial Behavior \& Research, 24(7), 1244-1263. https://doi.org/10.1108/IJEBR-11-2016-0396

Brawley, A. M., \& Pury, C. L. S. (2017). Little things that count: A call for organizational research on microbusinesses. Journal of Organizational Behavior, 38(6), 917-920. https://doi.org/http://dx. doi.org/10.1002/job.2184

Crane, L.D., Decker, R.A., Flaaen, A., Hamins-Puertolas, A., \& Kurz, C. (2020). Business exit during the COVID-19 pandemic: Non-traditional measures in historical context. Finance and Economics Discussion Series 2020-089. Washington: Board of Governors of the Federal Reserve System, https:// doi.org/10.17016/FEDS.2020.089 
Culkin, N. (2016). Entrepreneurial universities in the region: The force awakens? International Journal of Entrepreneurial Behavior \& Research, 22(1), 4-16. https://doi.org/10.1108/IJEBR-12-2015-0310

Devins, D., Gold, J., Johnson, S., \& Holden, R. (2005). A conceptual model of management learning in micro businesses : Implications for research and policy. Education + Training, 47(8/9), 540-551. https://doi.org/10.1108/00400910510633099

Drnevich, P. L., \& West, J. (2021). Performance implications of technological uncertainty, age, and size for small businesses. Journal of Small Business Management, 1-36. https://doi.org/10.1080/0047 $\underline{2778.2020 .1867733}$

Fielden, S. L., Davidson, M. J., \& Makin, P. J. (2000). Barriers encountered during micro and small business start-up in North-West England. Journal of Small Business and Enterprise Development, 7(4), 295-304. https://doi.org/10.1108/ EUM0000000006852

Gherhes, C., Williams, N., Vorley, T., \& Vasconcelos, A. C. (2016). Distinguishing micro-businesses from SMEs: A systematic review of growth constraints. Journal of Small Business and Enterprise Development, 23(4), 939-963. https://doi.org/ http://dx.doi.org/10.1108/JSBED-05-2016-0075

Gray, D., \& Jones, K. F. (2016). Using organisational development and learning methods to develop resilience for sustainable futures with SMEs and micro businesses. Journal of Small Business and Enterprise Development, 23(2), 474-494. https:// doi.org/10.1108/JSBED-03-2015-0031

Hayes, J. P., Chawla, S., K., \& Kathawala, Y. (2015). A comparative study of problems encountered in the development of small businesses in the U.S. and Mexico [research-article]. The Journal of Developing Areas, 49(3), 395-406. https://doi. org/10.1353/jda.2015.0175

Headd, B. (2017). Small Business Facts - The role of microbusiness employers in the economy. US

Small Business Administration. Retrieved 10/13/2020 from https://cdn.advocacy.sba.gov/ wp-content/uploads/2019/06/06120136/508FINALAug17Microbusiness.pdf

Hennekam, S., \& Bennett, D. (2017). Creative industries work across multiple contexts: common themes and challenges [JOURNAL]. Personnel Review, 46(1), 68-85. https://doi.org/10.1108/PR08-2015-0220

Jones, Simmons, G., Packham, G., Beynon-Davies, P., \& Pickernell, D. (2014). An exploration of the attitudes and strategic responses of sole-proprietor micro-enterprises in adopting information and communication technology. International
Small Business Journal, 32(3), 285-306. https:// doi.org/10.1177/0266242612461802

Kelliher, F., Reinl, L., Johnson, T. G., \& Joppe, M. (2018). The role of trust in building rural tourism micro firm network engagement: A multi-case study. Tourism Management, 68, 1-12. https://doi. org/10.1016/j.tourman.2018.02.014

Lean, J. (1998). Training and business development support for micro businesses in a peripheral area. Journal of European Industrial Training, 22(6), 231236. https://doi.org/10.1108/03090599810224684

Nieminen, L., \& Lemmetyinen, A. (2015). A value-creating framework for enhancing entrepreneurial learning in networks. Journal of Enterprising Communities, 9(1), 76-91. https://doi.org/ http://dx.doi.org/10.1108/JEC-04-2013-0012

Perren, L. (2000a). Factors in the growth of micro-enterprises (Part 1): Developing a framework. Journal of Small Business and Enterprise Development, (4), 366. https://doi.org/10.1108/ EUM0000000006691

Perren, L. (2000b). Factors in the growth of micro-enterprises (Part 2): Exploring the implications. Journal of Small Business and Enterprise Development, (1), 58. https://doi.org/10.1108/ EUM0000000006805

Raffo, C., Lovatt, A., Banks, M., \& O’Connor, J. (2000). Teaching and learning entrepreneurship for micro and small businesses in the cultural industries sector. Education + Training, 42(6), 356365. https://doi.org/10.1108/00400910010353653

Rupasingha, A. (2017). Local business ownership and local economic performance: evidence from US counties. Regional Studies, 51(5), 659-673. https://doi.org/10.1080/00343404.2015.1119264

Spence, L. J. (2016). Small Business Social Responsibility. Business \& Society, 55(1), 23-55. https://doi. org/10.1177/0007650314523256

Van Hoang, T. H., Gurău, C., Lahiani, A., \& Seran, T.-L. (2018). Do crises impact capital structure? A study of French micro-enterprises. Small Business Economics, 50(1), 181-199. https://doi. org/10.1007/s11187-017-9899-X

Yang, X. X. (2016). Key Success Factors of Small Business in a Southern Region of California (Publication Number 3729791) [D.B.A., Walden University]. ABI/INFORM Collection; ProQuest Dissertations \& Theses A\&I; ProQuest Dissertations \& Theses Global. Ann Arbor.

Yang, Y., \& Danes, S. M. (2015). Resiliency and Resilience Process of Entrepreneurs in New Venture Creation. Entrepreneurship Research Journal, 5(1), 1-30. https://doi.org/doi:10.1515/erj-2013-0076 


\section{Review}

This article was accepted under the constructive peer review option. For futher details, see the descriptions at:

http://mumabusinessreview.org/peer-review-options/

\section{Author}

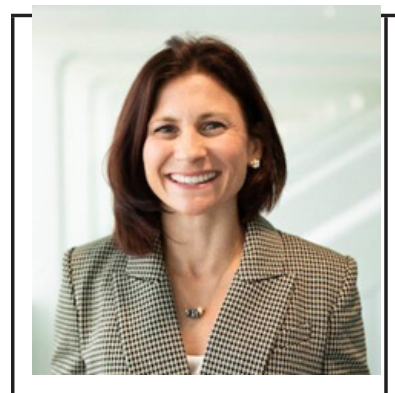

Debra Frank is a CPA and Enrolled Agent with more than 15 years' experience as an accountant. She is an owner of an accounting practice and an adjunct professor at Florida Polytechnic University and Valencia College. She earned an MBA, as well as, a master's degree in accounting and taxation, and a bachelor's degree in accountancy from Florida Gulf Coast University. She is a member of the DBA Cohort 2022 at the University of South Florida Muma College of Business. 